\title{
GENOTYPING OF DRUG-RESISTANT MYCOBACTERIUM TUBERCULOSIS ISOLATES FROM SOUTHERN KAZAKHSTAN
}

\author{
Tarlykov P. ${ }^{1}$, Atavliyeva S. ${ }^{1}$, Alenova A. ${ }^{2}$, Zholdybayeva E. ${ }^{1}$, Ramankulov Ye. ${ }^{1}$ \\ ${ }^{1}$ National Center for Biotechnology \\ 13/5, Korgalzhyn road, Astana, 010000, Kazakhstan \\ ${ }^{2}$ National Scientific Center of Phthisiopulmonology \\ 5 Bekkhozhin str., Almaty, 050010, Kazakhstan \\ tarlykov@biocenter.kz
}

\section{ABSTRACT}

The incidence of drug-resistant tuberculosis in Kazakhstan has risen over the last decades, making it a serious threat. The purpose of this study was to characterize $M$. tuberculosis isolates circulating in the south of Kazakhstan, based on mutations of known association with multidrugresistance and extensive drug resistance. A total of 58 clinical isolates of $M$. tuberculosis with drug resistance from southern Kazakhstan were selected. Seven genetic loci were sequenced, namely, $r p o B$ (for resistance to RIF), $k a t G$, inh $A$ (for resistance to INH), embB (for resistance to EMB), as well as the $\operatorname{gyr} A, \operatorname{gyr} B$ (for resistance to CIP and OFX) and rrs (for resistance to KAN, AMK, and CPR). In addition, mutations in codon 315 of $k a t G$ ( $n=53$; $91.4 \%)$, in codon 531 of the $r p o B(n=45 ; 77.6 \%)$, at the position of 1401 $\mathrm{A} / \mathrm{G}$ of $\operatorname{rrs}(\mathrm{n}=33 ; 56.9 \%)$ and in the codon 94 of the $\operatorname{gyr} A$ were found to be prevalent in the samples. MIRU-VNTR typing showed that most isolates belong to the Beijing family $(n=53 ; 94.4 \%)$. Whole genome sequencing of a single $M$. tuberculosis strain from southern Kazakhstan was conducted. The emergence of drug-resistance is characteristic of the Beijing family, which may explain the increase in the incidence rates of resistant forms of tuberculosis in Kazakhstan.

Keywords: Mycobacterium tuberculosis, WGS, antibiotic resistance, genotyping, MIRU-VNTR.

\section{INTRODUCTION}

The evolving drug resistance of $M$. tuberculosis contributes to the status of tuberculosis as the deadliest infectious disease. According to the World Health Organization report (2018), the causative agent of tuberculosis has resulted in 1.3 million deaths and 10.0 million people developed TB disease worldwide in 2017 [1]. As of 2018, the epidemiological situation of tuberculosis in the Republic of Kazakhstan remained tense. One of the main reasons is the high incidence of multidrug-resistant and extensively drug-resistant tuberculosis (MDR and XDR). It should be noted that the treatment of these forms of tuberculosis is expensive and toxic.

The rise of antimicrobial resistance in Kazakhstan is due to a number of objective reasons. Among them are social factors including poverty, unemployment, alcohol and drug abuse, as well as the spread of infection in closed environments, such 
as correctional institutions. It is well-known that prisons are reservoirs of tuberculosis infection, including those with resistance to major anti-TB drugs [1]. In addition, in the 1990s, there was the appointment of inadequate treatment regimens in Kazakhstan, interruptions in the supply of drugs, the absence of treatment standards, and the low socio-economic status of the patient [2,3]. All this led to the rise of antimicrobial resistance and deterioration of the epidemiological situation. It has been proven that strict adherence to the WHO strategy of controlled TB treatment makes it possible to prevent the development of drug resistance in patients with established susceptibility to anti-tuberculosis drugs before the start of treatment $[4,5]$.

The largest proportion of TB mortality in 2017 was patients with resistant forms of tuberculosis according to the National Scientific Center of Phthisiopulmonology (NSCP, Ministry of Health of the Republic of Kazakhstan). Accumulation of ineffectively treated patients with antimicrobial resistance contributes to the overall deterioration of the TB situation.

The global emergence of MDR and XDR-TB increases the need to introduce new effective methods to diagnose resistant forms of TB. The purpose of this study was to characterize $M$. tuberculosis isolates, based on mutations of known association with multidrug-resistance and extensive drug resistance circulating in the cities of Almaty, Taraz, Taldykorgan and Talgar. Phylogenetic variability was identified based on MIRU-VNTR typing. In addition, WGS sequencing of a single M. tuberculosis strain from southern Kazakhstan was conducted.

\section{Materials and methods}

\section{Samples}

Clinical isolates of $M$. tuberculosis were isolated by the reference laboratory of NSCP (Almaty) from sputum samples of patients with newly diagnosed and chronic drug-resistant forms of pulmonary tuberculosis. A total of 58 clinical isolates with various drug resistance profiles were collected in Almaty (27 samples), Talgar (20 samples), Taldykorgan (8 samples) and Taraz (3 samples). DNA isolation of $M$. tuberculosis was carried out in the reference laboratory according to the guidelines for MIRU-VNTR typing (http://www.miru-vntrplus.org). MTBDR Plus, MTBDR sl (Hain LifeScience) and Bactec MGIT 960 methods were used by the reference laboratory to test $M$. tuberculosis susceptibility to first-line drugs (isoniazid, rifampin, streptomycin, and ethambutol) and second-line drugs (capreomycin, ethionamide, ofloxacin, kanamycin, and amikacin). Susceptible samples were not included in the sample group. Afterward, genetic analysis of the samples was carried out, including sequencing of genes associated with resistance to the first- and second-line drugs, whole-genome sequencing and MIRU-VNTR analysis.

Sequencing

DNA from the clinical isolates of $M$. tuberculosis was sequenced to identify mutations associated with resistance to first- and second-line drugs. PCR was carried out in a mixture containing dNTP, PCR buffer, $2.5 \mathrm{mM} \mathrm{MgCl}_{2}, 1$ unit of Taq polymerase (Fermentas) and $10 \mathrm{pmol}$ of each primer (table 1). A universal amplification profile was used, for all genetic loci: $94^{\circ} \mathrm{C}-5 \mathrm{~min} ; 30$ cycles: $94^{0} \mathrm{C}$ for $30 \mathrm{sec}, 63^{\circ} \mathrm{C}$ for $30 \mathrm{sec}, 72^{\circ} \mathrm{C}$ for $30 \mathrm{sec} ; 72^{\circ} \mathrm{C}$ for $10 \mathrm{~min}$ and storage at $4^{\circ} \mathrm{C}$. Dephosphorylation and purification of PCR products were performed using alkaline phosphatase and exonuclease I (Fermentas). Sequencing was performed using the BigDye Terminator v3.1 Cycle Sequencing Kit and the ABI 3730 Genetic Analyzer (Applied Biosystems) according to the manufacturer's instructions. In the sequencing reaction, the same primers were used in the amplification reaction. The alignment and comparative analysis of the obtained $r p o B, k a t G$, inh $A, e m b B, g y r A, g y r B$ genes, and $r r s$ promoter 
region were performed using the reference sequence of $M$. tuberculosis H37Rv (NC_000962) strain using SeqScape 2.1 (Applied Biosystems).

Table 1. Primers used to amplify selected genes of M. tuberculosis

\begin{tabular}{|c|c|c|c|}
\hline Genetic locus & Primer & $\begin{array}{l}\text { Sequence } \\
\left(5^{\prime} \rightarrow 3^{\prime}\right)\end{array}$ & $\begin{array}{c}\text { Expected PCR } \\
\text { product (bp) }\end{array}$ \\
\hline гров & $\begin{array}{l}\text { MtrpoBf } \\
\text { MtrpoBr }\end{array}$ & $\begin{array}{l}\text { gaggcgatcacaccgcagac } \\
\text { ggtacggcgtttcgatgaac }\end{array}$ & 321 \\
\hline$k a t G$ & $\begin{array}{l}\text { MtkatGf } \\
\text { MtkatGr }\end{array}$ & $\begin{array}{l}\text { acccgaggctgctccgctgg } \\
\text { cagctcccactcgtagccgt }\end{array}$ & 168 \\
\hline $\operatorname{inh} A$ & $\begin{array}{l}\text { MtfabGf } \\
\text { MtfabGr }\end{array}$ & $\begin{array}{l}\text { gcctcgctgcccagaaagg } \\
\text { ctccggatccacggtgggt }\end{array}$ & 320 \\
\hline$e m b B$ & MtEB406F MtEB406R & $\begin{array}{l}\text { ccatggtcttgctgacc } \\
\text { cacacccagtgtgaatgc }\end{array}$ & 170 \\
\hline gyrA & $\begin{array}{l}\text { gyrAF } \\
\text { gyrAR }\end{array}$ & $\begin{array}{l}\text { cagctacatcgactatgcga } \\
\text { gggcttcggtgtacctcat }\end{array}$ & 852 \\
\hline $\operatorname{gyr} B$ & $\begin{array}{l}\text { gyrBF } \\
\text { gyrBR }\end{array}$ & $\begin{array}{l}\text { ccaccgacatcggtggatt } \\
\text { ctgccacltgagtttlgtaca }\end{array}$ & 429 \\
\hline$r r s$ & $\begin{array}{l}\operatorname{rrsF} \\
\operatorname{rrsR}\end{array}$ & $\begin{array}{l}\text { caggtaaggttcttcgcgttg } \\
\text { gttcggatcggggtctgcaa }\end{array}$ & 305 \\
\hline
\end{tabular}

Next-generation sequencing

Ion Torrent sequencing technology was used to sequence a single isolate from Almaty (\#97). Genomic DNA of mycobacteria was processed according to the recommended Ion Torrent library preparation protocol. Barcode \#03 was assigned to the sample using Ion Xpress Barcode Adapters Kit (Thermo). DNA diluted to $20 \mathrm{ng} / \mu 1$ was used to prepare the library. Prepared library was used in the emulsion PCR with Ion PGM Template OT2 400 Kit on Ion OneTouch2 Instrument (Thermo). Then templatepositive Ion PGM Template OT2 400 Ion Sphere Particles were recovered by Ion PGM Template OT2 Solutions 400 Kit. Quality assessment of the unenriched, templatepositive ISPs was done on the Qubit 2.0 fluorimeter. Enrichment of the templatepositive ISPs was conducted using Ion PGM Template OT2 Solutions $400 \mathrm{Kit}$, Ion PGM Template OT2 Supplies $400 \mathrm{Kit}$, and Ion PGM Enrichment Beads according to the manufacturer's protocol. The sequencing was conducted on Ion Torrent PGM sequencing platform using Ion PGM ${ }^{\mathrm{TM}}$ HiQ sequencing kit (Thermo) according to the manufacturer's instructions. Data analysis was conducted in PhyResSE v.1 (https://bioinf.fz-borstel.de/mchips/phyresse/).

\section{MIRU-VNTR}

Analysis of the number of tandem repeats of $M$. tuberculosis clinical isolates was performed using twenty-four locus MIRU-VNTR scheme. Primers for the twentyfour locus genotyping were previously reported (http://www.miru-vntrplus.org/MIRU/). Amplification products were analyzed by electrophoresis in $2 \%$ agarose gel in $1 \times \mathrm{TAE}-$ buffer, followed by staining with ethidium bromide. The number of tandem repeats in the corresponding locus was calculated based on the size of the PCR product, determined by the size of 100 bp DNA Ladder (GeneRuler, Fermentas), using the Quantity One v.4.4.0 software package (BioRad). The phylogenetic tree was constructed using the unweighted pair group method with arithmetic mean (UPGMA) using weighted pairing (http://www.miru-vntrplus.org/MIRU/). 


\section{RESULTS AND DISCUSSION}

Genotypic predictions of the susceptibility of $58 \mathrm{M}$. tuberculosis isolates to firstline anti-TB drugs (rifampin, isoniazid, and ethambutol) was assessed by sequencing of $r p o B, k a t G, e m b B$ and the promoter region of the inhA gene. According to the sequencing of data, most of the samples had a high-level resistance mutation in codon 315 of $k a t G(n=53 ; 91.4 \%)$, resulting to the replacement of serine by threonine $(\mathrm{AGC} \rightarrow \mathrm{ACC})[6,7]$. Sequencing of the $r p o B$ revealed a high-level resistance mutation in the codon 450 ( $E$. coli $\mathrm{S} 531 \mathrm{~L})$ with the replacement of serine by leucine $(\mathrm{n}=45$; $77.6 \%$ ). In addition, a mutation $-15 \mathrm{C} / \mathrm{T}$ in the promoter region of $i n h A$ was found in two samples $(\mathrm{n}=2 ; 3.5 \%)$. Sequencing of the $r p o B$ gene showed a mixed infection in two isolates (figure 1).

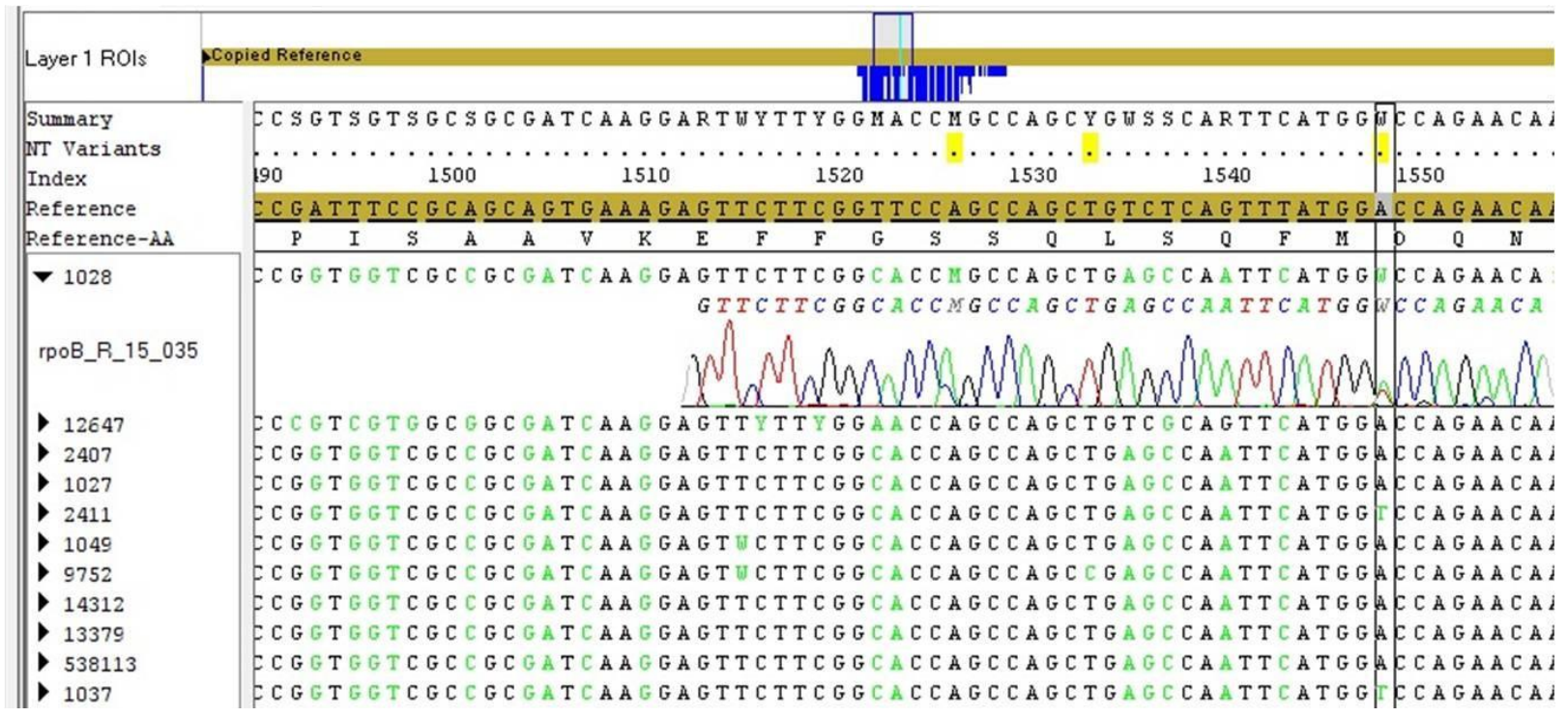

Fig. 1. Chromatogram of the nucleotide sequence of the $r p o B$ gene

Analysis of the nucleotide sequence of the $e m b B$ gene revealed a mutation in the codon 406 of the $e m b B$ gene with the replacement of Gly $\rightarrow$ Asp $(n=6 ; 10.3 \%)$. The detected mutations, as well as their frequencies, are listed in table 2.

Table 2. High confidence SNPs of M. tuberculosis isolates inferred from sequencing

\begin{tabular}{|c|c|c|c|c|}
\hline Gene & Codon & $\begin{array}{c}\text { Nucleotide } \\
\text { substitution }\end{array}$ & $\begin{array}{c}\text { Amino acid } \\
\text { substitution }\end{array}$ & $\begin{array}{c}\text { Number of isolates with } \\
\text { mutations }(\%), \\
(\mathrm{n}=58)\end{array}$ \\
\hline \multicolumn{5}{|c|}{ Mutations causing resistance to first-line drugs } \\
\hline$k a t G$ & 315 & AGC/ACC & Ser $\rightarrow$ Thr & $53(91,4)$ \\
\hline inhA & $-15 \mathrm{C} / \mathrm{T}$ & $-15 \mathrm{C} / \mathrm{T}$ & - & $2(3,5)$ \\
\hline $\mathrm{rpoB}$ & $450(531)$ & TCG/TTG & Ser $\rightarrow$ Leu & $45(77,6)$ \\
\hline \multirow{2}{*}{$e m b B$} & 406 & GGC/GAC & Gly $\rightarrow$ Asp & $6(10,3)$ \\
\hline
\end{tabular}




\begin{tabular}{|c|c|c|c|c|}
\hline \multicolumn{5}{|c|}{ Mutations causing resistance to second-line drugs } \\
\hline \multirow{3}{*}{ gyrA } & 90 & GCG $\rightarrow$ GTG & Ala $\rightarrow$ Val & $5(8,6)$ \\
\cline { 2 - 5 } & 91 & TCG $\rightarrow$ CCG & Ser $\rightarrow$ Pro & $5(8,6)$ \\
\cline { 2 - 5 } & 94 & GAC $\rightarrow$ AAC & Asp $\rightarrow$ Asn & $6(10,3)$ \\
\cline { 2 - 5 } & 94 & GAC $\rightarrow$ GCC & Asp $\rightarrow$ Ala & $10(17,2)$ \\
\cline { 2 - 5 } & 94 & GAC $\rightarrow$ TAC & Asp $\rightarrow$ Tyr & $5(8,6)$ \\
\cline { 2 - 5 } & 94 & GAC/TGC & Asp $\rightarrow$ Cys & $2(3,5)$ \\
\cline { 2 - 5 } & 94 & GAC/GGC & Asp $\rightarrow$ Gly & $16(27,6)$ \\
\hline gyrB & 500 & GAC/AAC & Asp/Asn & $1(1,7)$ \\
\hline$r r s$ & $1401 \mathrm{~A} / \mathrm{G}$ & $1401 \mathrm{~A} / \mathrm{G}$ & - & $33(56,9)$ \\
\hline
\end{tabular}

Further analysis of genotypic prediction of the susceptibility to second-line antiTB drugs (capreomycin, ofloxacin, kanamycin, and amikacin) was carried by sequencing the gyrA, gyrB and $r r s$ genes. According to the results of DNA sequencing of the gyrA, there is a major polymorphism at codon 95 , leading to the replacement of $\mathrm{Ser} \rightarrow \operatorname{Thr}(\mathrm{n}=57 ; 98.3 \%)$. Interestingly, the non-synonymous S95T change is not related to antibiotic resistance as well as any other variant at codon 95 and considered as a natural polymorphism [8]. In addition, S95T change was found to be a phylogenetically informative polymorphism [9]. In contrast, mutations with confirmed clinical significance were found in codon 94 of $g y r A$ [7]. Most frequent mutations among them are GAC/GGC leading to the replacement of aspartic acid by glycine $(\mathrm{n}=$ $16 ; 27.6 \%), \mathrm{GAC} / \mathrm{GCC}(\mathrm{Asp} \rightarrow \mathrm{Ala} ; \mathrm{n}=10 ; 17.2 \%), \mathrm{GAC} / \mathrm{AAC}$ mutation $(\mathrm{Asp} \rightarrow \mathrm{Asn} ; \mathrm{n}$ $=6 ; 10.3 \%$ ) and others. For the first time, an amino acid substitution of aspartic acid by cysteine Asp $\rightarrow$ Cys at codon $94(n=2 ; 3.5 \%)$ was identified in two local samples (figure 2).

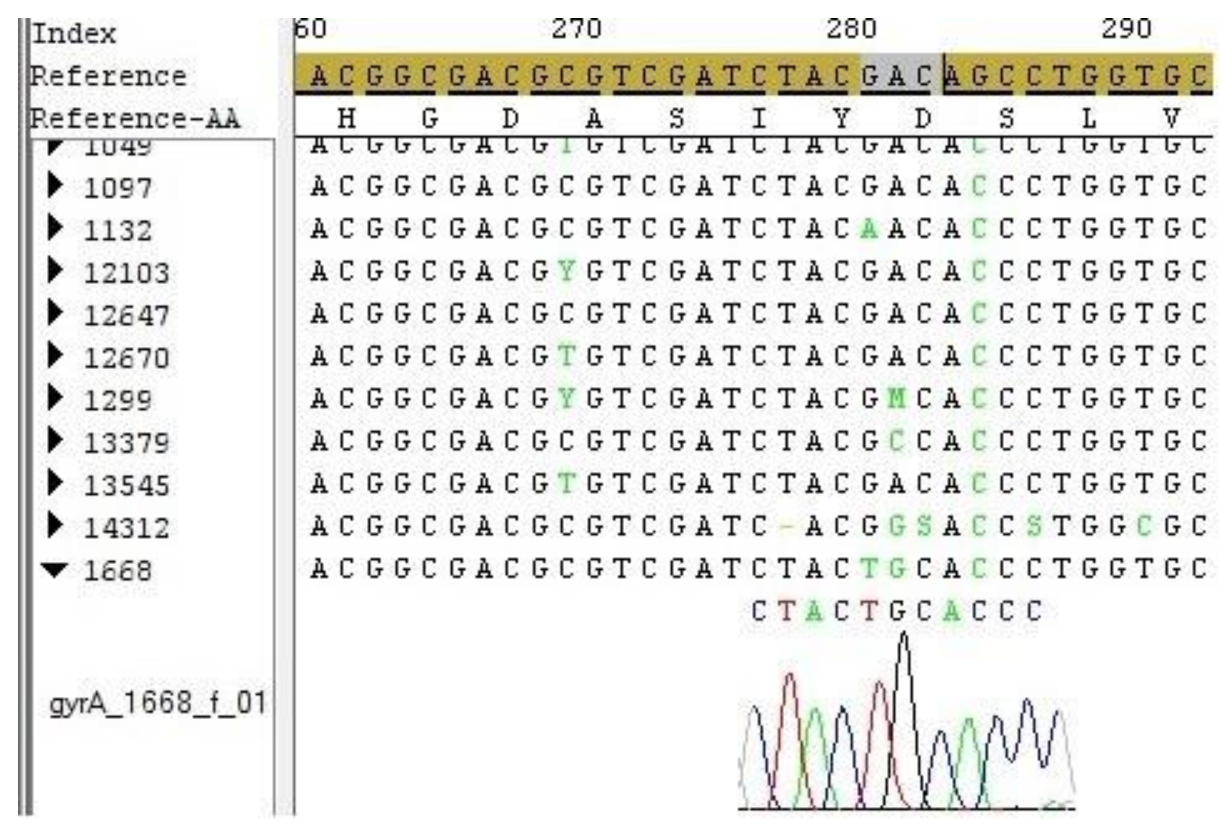

Fig. 2. Chromatogram of the nucleotide sequence with amino acid substitution Asp $\rightarrow$ Cys (GAC/TGC, \#1668) in the gyrA gene 
In the $\operatorname{gyr} B$, also causing resistance to fluoroquinolones, a mutation was found in the codon $500(\mathrm{n}=1 ; 1.7 \%)$. Sequencing of the rrs gene showed the presence of mutations at position $1401 \mathrm{~A} / \mathrm{G}(\mathrm{n}=33 ; 56.9 \%)$. In addition, the sequencing results pointed out two cases of mixed infections. In one of the samples, the sequence of the gyrA has indicated mixed infection, while another case was detected from the sequence of the rrs gene at position 1401.

It should be noted that all 58 isolates were selected after testing susceptibility using the MTBDR Plus, MTBDR sl, and Bactec MGIT methods. The purpose of the subsequent sequencing was to detect both previously known and new mutations in the genes of known association with multidrug-resistance and extensive drug resistance. As a result, extensive drug resistance was genetically confirmed in half of the isolates $(\mathrm{n}=29,50 \%)$. These isolates, in addition to resistance to the first-line drugs, harbored mutations in the gyrA, gyrB and $r r s$ genes. Phenotypic susceptibility of the studied isolates was correctly predicted for rifampin and isoniazid based on sequencing data.

Next-generation sequencing of the single M. tuberculosis isolate was conducted on Ion Torrent platform with $27 \mathrm{x}$ genome coverage. M. tuberculosis antibiotic susceptibility and strain lineage (family) was analyzed using PhyResSE (figure 3) [8]. 


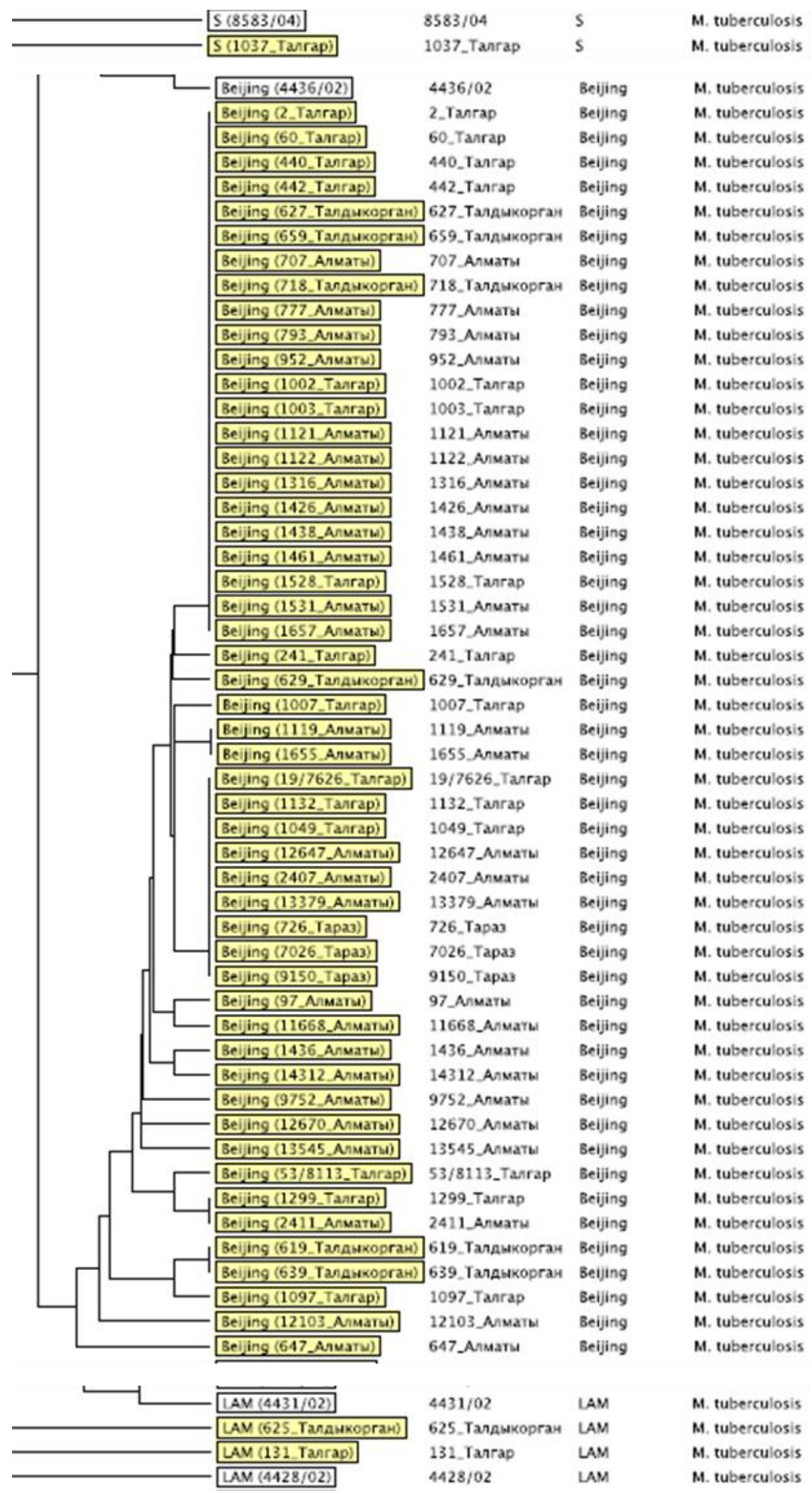

Fig. 3. Dendrogram of phylogenetic similarity of the studied isolates (highlighted in yellow), based on the results of genotyping of 24 MIRU-VNTR loci. For comparison, MIRU-VNTR profiles of M. tuberculosis control strains from the MIRU-VNTR database were used (not highlighted). 
The PhyResSE pipeline combines well-established methods from FastQC, BWA, QualiMap, and SAMtools. In-depth quality control was applied to both reads and mapping performance before classifying the sample. Strain lineage and antibiotic susceptibility of the isolate \#97 were identified as XDR and Beijing, respectively [9]. The isolate conferred the following high confidence SNPs (table 3).

Table 3. High confidence SNPs of M. tuberculosis isolate \#97 inferred from WGS data

\begin{tabular}{|l|r|l|l|l|l|l|}
\hline Gene & $\begin{array}{r}\text { Variant } \\
\text { position }\end{array}$ & AA change & $\begin{array}{l}\text { Codon } \\
\text { change }\end{array}$ & $\begin{array}{l}\text { Reference } \\
\text { SNP }\end{array}$ & $\begin{array}{l}\text { SNP in } \\
\text { isolate }\end{array}$ & \multicolumn{1}{|c|}{ Antibiotic } \\
\hline gyrA & 281 & Asp94Gly & gac/ggc & $\mathrm{A}$ & $\mathrm{G}$ & $\begin{array}{l}\text { Fluoroquinolones (FQ) } \\
{[16]}\end{array}$ \\
\hline$r p o B$ & 1349 & Ser450Leu & tcg/ttg & $\mathrm{C}$ & $\mathrm{T}$ & Rifampicin (RMP) [16] \\
\hline$r p s L$ & 128 & Lys43Arg & aag/agg & $\mathrm{A}$ & $\mathrm{G}$ & Streptomycin (SM) [17] \\
\hline$r r s$ & 1401 & --- & ribosomal & $\mathrm{A}$ & $\mathrm{G}$ & $\begin{array}{l}\text { Amikacin (AMK), } \\
\text { Kanamycin (KAN), } \\
\text { Capreomycin (CPR) [16] }\end{array}$ \\
\hline katG & 944 & Ser315Thr & agc/acc & $\mathrm{C}$ & $\mathrm{G}$ & Isoniazid (INH) [18] \\
\hline pncA & 34 & Asp12Asn & gac/aac & $\mathrm{C}$ & $\mathrm{T}$ & Pyrazinamide (PZA) [19] \\
\hline embB & 916 & Met306Val & atg/gtg & $\mathrm{A}$ & $\mathrm{G}$ & Ethambutol (EMB) [16] \\
\hline
\end{tabular}

The final part of this work was the determination of 24-loci MIRU-VNTR profiles of 58 clinical isolates of $M$. tuberculosis. A MIRU-VNTR profile, corresponding to the number of tandem repeats in a particular locus was obtained for every TB isolate. Four out of 58 samples were excluded from the analysis since they showed multiple values for one or more MIRU-VNTR loci, which indicated the presence of mixed infections. Comparison of 54 MIRU-VNTR profiles with the database showed that the predominant group of isolates $(n=51 ; 94.4 \%)$ belong to the Beijing family. Two isolates $(3.7 \%)$ were identified as LAM family and one isolate $(\mathrm{n}=$ $1 ; 1.9 \%)$ as S-type. An analysis of earlier data showed that the appearance of multiple and extensive drug resistance was characteristic of the Beijing family [10-13].

\section{CONCLUSION}

The analysis of drug-resistant Mycobacterium tuberculosis isolates from southern Kazakhstan revealed genetic features of association with drug resistance to first- and second-line drugs using DNA sequencing and MIRU-VNTR genotyping of $M$. tuberculosis. Strains were isolated from 58 patients with newly diagnosed and with chronic drug-resistant forms of pulmonary tuberculosis. Substitutions in the codon 315 of $k a t G$ gene $(\mathrm{n}=53 ; 91.4 \%)$, codon 531 of the $r p o B$ gene $(\mathrm{n}=45 ; 77.6 \%)$ and in the $1401 \mathrm{~A} / \mathrm{G}$ position of the $r r s$ gene $(\mathrm{n}=33 ; 56.9 \%)$ were found to be dominant in the studied sample. In addition, nearly all isolates had a polymorphism in the codon 95 of the gyrA gene ( $\mathrm{n}=57 ; 98.3 \%$ ), although its association with drug resistance is not clear. In the course of this study, a rarely described replacement of aspartic acid by cysteine in the codon 94 of the gyrA gene was found. In general, analysis of mutations in the genes responsible for resistance to first- and second-line drugs has identified extensively drugresistance in half of the isolates studied $(n=29 ; 50 \%)$.

In addition, whole-genome sequencing of the single isolate of the Beijing family from the south of Kazakhstan has confirmed its XDR status. Whole-genome sequencing is a certainly powerful technique that provides complete antibiotic resistance and epidemiology profile. However, it is not affordable for routine use in the majority of developing countries with a limited state healthcare budget. 
MIRU-VNTR typing showed that most isolates from the south of Kazakhstan belong to the Beijing family $(\mathrm{n}=53 ; 94.4 \%)$. At the same time, two isolates $(\mathrm{n}=2$; $3.7 \%)$ belonged to the LAM family and one isolate $(\mathrm{n}=1 ; 1.9 \%)$ to the $\mathrm{S}$ family. It should be noted that low genetic diversity was observed among the isolates. At the same time, the Beijing family, which represents the vast majority of isolates in the studied sample, has a known capacity to acquire drug resistance $[14,15]$. It may partially explain the increase in the incidence rates of resistant forms of tuberculosis in the Republic of Kazakhstan.

\section{Acknowledgments}

This study was supported by the Ministry of Education and Science of the Republic of Kazakhstan (grant No. AP05130238).

\section{REFERENCES}

1. Global tuberculosis report 2018. World Health Organization. - 2018. - URL: http://www.who.int/tb/publications/global report/en/.

2. Bumburidi E., Ajeilat S., Dadu A. et al. Progress toward tuberculosis control and determinants of treatment outcomes--Kazakhstan, 2000-2002. MMWR supplements, 2006, vol. 55, no. 1, pp. 11-15.

3. Favorov M., Belilovsky E., Aitmagambetova I. et al. Tuberculosis deaths averted by implementation of the DOTS strategy in Kazakhstan. International Journal of Tuberculosis and Lung Disease, 2010, vol. 14, no. 12, pp. 1582-1588.

4. Davis A., Terlikbayeva A., Aifah A. et al. Risks for tuberculosis in Kazakhstan: implications for prevention. International Journal of Tuberculosis and Lung Disease, 2017, vol. 21, no. 1, pp. 86-92. doi: 10.5588/ijtld.15.0838.

5. Rios M., Monleon-Getino T. A graphical study of tuberculosis incidence and trends in the WHO's European region (1980-2006). European Journal of Epidemiology, 2009, vol. 24, no. 7, pp. 381-387. doi: 10.1007/s10654-009-9347-6.

6. Ahmad S., Mokaddas E. Contribution of AGC to ACC and other mutations at codon 315 of the katG gene in isoniazid-resistant Mycobacterium tuberculosis isolates from the Middle East. Int J Antimicrob Agents, 2004, vol. 23, no. 5, pp. 473-479. doi: 10.1016/j.ijantimicag.2003.10.004.

7. Takiff H.E., Salazar L., Guerrero C. et al. Cloning and nucleotide sequence of Mycobacterium tuberculosis gyrA and gyrB genes and detection of quinolone resistance mutations. Antimicrob Agents Chemother, 1994, vol. 38, no. 4, pp. 773-780.

8. Feuerriegel S., Schleusener V., Beckert P. et al. PhyResSE: a Web Tool Delineating Mycobacterium tuberculosis Antibiotic Resistance and Lineage from Whole-Genome Sequencing Data. J Clin Microbiol, 2015, vol. 53, no. 6, pp. 19081914. doi: 10.1128/jcm.00025-15.

9. Feuerriegel S., Koser C.U., Niemann S. Phylogenetic polymorphisms in antibiotic resistance genes of the Mycobacterium tuberculosis complex. J Antimicrob Chemother, 2014, vol. 69, no. 5, pp. 1205-1210. doi: 10.1093/jac/dkt535.

10. Allix C., Supply P., Fauville-Dufaux M. Utility of fast mycobacterial interspersed repetitive unit-variable number tandem repeat genotyping in clinical mycobacteriological analysis. Clin Infect Dis, 2004, vol. 39, no. 6, pp. 783-789. doi: $10.1086 / 423383$.

11. Drobniewski F., Balabanova Y., Ruddy M. et al. Rifampin- and multidrugresistant tuberculosis in Russian civilians and prison inmates: dominance of the beijing strain family. Emerg Infect Dis, 2002, vol. 8, no. 11, pp. 1320-1326. doi: 10.3201/eid0811.020507. 
12. Dymova M.A., Cherednichenko A.G., Alkhovik O.I. et al. Characterization of extensively drug-resistant Mycobacterium tuberculosis isolates circulating in Siberia. BMC Infect Dis, 2014, vol. 14, no. 478, pp. 1471-2334.

13. Kubica T., Agzamova R., Wright A. et al. The Beijing genotype is a major cause of drug-resistant tuberculosis in Kazakhstan. Int J Tuberc Lung Dis, 2005, vol. 9, no. 6 , pp. 646-653.

14. Mokrousov I. Molecular structure of Mycobacterium tuberculosis population in Russia and its interaction with neighboring countries. Int J Mycobacteriol, 2015, vol. 1, no., pp. 56-57.

15. Skiba Y., Mokrousov I., Ismagulova G. et al. Molecular snapshot of Mycobacterium tuberculosis population in Kazakhstan: a country-wide study. Tuberculosis, 2015, vol. 95, no. 5, pp. 538-546.

16. Campbell P.J., Morlock G.P., Sikes R.D. et al. Molecular detection of mutations associated with first- and second-line drug resistance compared with conventional drug susceptibility testing of Mycobacterium tuberculosis. Antimicrob Agents Chemother, 2011, vol. 55, no. 5, pp. 2032-2041. doi: 10.1128/aac.01550-10.

17. Feuerriegel S., Oberhauser B., George A.G. et al. Sequence analysis for detection of first-line drug resistance in Mycobacterium tuberculosis strains from a high-incidence setting. BMC Microbiol, 2012, vol. 12, no., pp. 90. doi: 10.1186/14712180-12-90.

18. Marttila H.J., Soini H., Huovinen P. et al. katG mutations in isoniazidresistant Mycobacterium tuberculosis isolates recovered from Finnish patients. Antimicrob Agents Chemother, 1996, vol. 40, no. 9, pp. 2187-2189.

19. Scorpio A., Lindholm-Levy P., Heifets L. et al. Characterization of pncA mutations in pyrazinamide-resistant Mycobacterium tuberculosis. Antimicrob Agents Chemother, 1997, vol. 41, no. 3, pp. 540-543.

\title{
ОНТУСТІК ҚАЗАҚСТАНДА ТАРАҒАН ТУБЕРКУЛЕЗ МИКОБАКТЕРИЯЛАРЫНЫН ДӘРІГЕ ТӨЗІМДІ ИЗОЛЯТТАРЫН ГЕНОТИПТЕУ
}

\author{
Тарлыков П. ${ }^{1}$, Атавлиева С. ${ }^{1}$, Аленова А. ${ }^{2}$, Жолдыбаева Е. ${ }^{\text {, }}$ \\ Раманқұлов Е. ${ }^{1}$ \\ ${ }^{1}$ Ұлттық биотехнология ортальвы, \\ Қорвалжын тас жоль, 13/5, Нұр-Султан, 010000, Қазақсстан \\ ${ }^{2}$ Фтизиопульмонология Ұлттық вылылми орталызы \\ Бекхожин көшесі, 5, Алматы, 050010, Қазақсстан \\ tarlykov@biocenter.kz
}

\section{ТYЙІН}

Соңғы онжылдықта Қазақстанда дәрі-дәрмекке төтеп беретін туберкулез аурулар саны өсті, ал бұл қауіпті жағдай. Зерттеудің мақсаты, Қазақстанның оңтүстігінде тараған M. tuberculosis изоляторларын көптеген дәрі-дәрмекке төзімділігі мен кең ауқымды дәрілерге төзімділігімен байланысты белгілі мутациялар негізінде сипаттау болды. Оңтүстік Қазақстаннан дәрі-дәрмекке төзімді жалпы 58 M. tuberculosis клиникалық изоляторы іріктеліп алынды. Жеті генетикалық локусқа секвендеу жүргізілді: rpoB (RIF тұрақтылығы), katG, inhA (INH тұрақтылығы), embB (ЕМB тұрақтылығы), сондай-ақ gyrA, gyrB (CIP және OFX тұрақтылығы) 
және rrs (KAN, AMK және CPR тұрақтылығы). Сонымен қатар, мутациялар 315 katG (n $=53 ; 91,4 \%)$ кодонында, 531 rроВ $(n=45 ; 77,6 \%)$ кодында, 1401 жағдайында $A / G$ ауыстыру rrs $(\mathrm{N}=33 ; 56,9 \%)$ және 94 gyrA кодонында үлгілерде табылды. MIRU-VNTR талдау көрсеткендей, көптеген изоляттар Beijing $(n=53 ; 94,4 \%)$ отбасына тиесілі. Оңтүстік Қазақстаннан алынған M. tuberculosis бір штаммына толық геномдық секвенирленуі жүргізілді. Дәріге төзімділіктің пайда болуы Beijing тобына тән, Қазақстандағы туберкулездің резистенттік түрімен ауырудың өршуін түсіндіре алады.

Негізгі сөздер: Mycobacterium tuberculosis, WGS, антибиотиктерге төзімділік, генотиптеу, MIRU-VNTR.

\title{
ГЕНОТИПИРОВАНИЕ ЛЕКАРСТВЕННО-УСТОЙЧИВЫХ ИЗОЛЯТОВ МИКОБАКТЕРИИ ТУБЕРКУЛЕЗА ИЗ ЮЖНОГО КАЗАХСТАНА
}

\author{
Тарлыков П. ${ }^{1}$, Атавлиева С. ${ }^{1}$, Аленова А. ${ }^{2}$, Жолдыбаева Е. ${ }^{\text {, }}$ \\ Раманкулов Е. ${ }^{1}$ \\ ${ }^{1}$ Национальный иеентр биотехнологии, \\ Кургальжинское шоссе, 13/5, Нур-Султан, 010000, Казахстан \\ ${ }^{2}$ Национальный научный иентр фтизиопульмонологии, \\ улица Бекхожина, 5, Алматы, 050010, Казахстан \\ tarlykov@biocenter.kz.
}

\section{АБСТРАКТ}

За последние десятилетия заболеваемость лекарственно-устойчивым туберкулезом в Казахстане возросла, что делает его серьезной угрозой. Цель исследования состояла в том, чтобы охарактеризовать изоляты M. tuberculosis, циркулирующие на юге Казахстана, на основе известных мутаций связанных с множественной лекарственной устойчивостью и широкой лекарственной устойчивостью. Всего было отобрано 58 клинических изолятов $M$. tuberculosis с лекарственной устойчивостью из южного Казахстана. Были секвенированы семь генетических локусов, а именно гроB (устойчивость к RIF), katG, inhA (устойчивость к INH), embB (устойчивость к ЕМВ), а также gyrA, gyrB (устойчивость к СIP и ОFХ) и rrs (устойчивость к KAN, AMK и CPR). Кроме того, мутации в кодоне 315 katG $(\mathrm{n}=53 ; 91,4 \%)$, в кодоне 531 rроB $(\mathrm{n}=45 ; 77,6 \%)$, в положении 1401 замена A/G в $r r s(n=33 ; 56,9 \%)$ и в кодоне 94 gyrA были обнаружены в образцах. Tипирование MIRU-VNTR показало, что большинство изолятов принадлежат к семейству Beijing $(n=53 ; 94,4 \%)$. Проведено полногеномное секвенирование одного штамма $M$. tuberculosis из Южного Казахстана. Появление лекарственной устойчивости характерно для семейства Beinjing, что может объяснить увеличение заболеваемости резистентными формами туберкулеза в Казахстане.

Ключевые слова: Mycobacterium tuberculosis, WGS, резистентность к антибиотикам, генотипирование, MIRU-VNTR. 